\title{
Legenda Bali dan Implementasinya dalam Budaya Kehidupan dan Industri Pelancongan Balinese Legends and Its Implementation in Culture of Life and Tourism Industry
}

\author{
MOHAMAD LUTHFI ABDUL RAHMAN \\ Bahagian Kesusasteraan, Pusat Pengajian Ilmu Kemanusiaan, Universiti Sains Malaysia, \\ 11800 Pulau Pinang.luthfi@usm.my \\ Diterima: 10 Oktober 2017 / Dibaiki: 2 Disember 2017
}

\begin{abstract}
Abstrak Makalah ini membicarakan tentang legenda terpilih yang terdapat di Pulau Bali, Indonesia. Cerita lisan ini dikaji dan dianalisis untuk memperlihatkan bentuk sebenar legenda di Bali dan bagaimana ia diimplementasi dalam budaya kehidupan masyarakat Bali sehingga hari ini. Cerita lisan yang dikaji ini juga merupakan cerita-cerita yang dianggap penting kepada masyarakat dan pada masa yang sama cerita ini dianggap suci oleh penganut Hindu di Bali. Makalah ini bertitik tolak daripada pandangan Mohd Khalid Taib (1991) dan Harun Mat Piah (2003) yang melihat perkaitan rapat antara legenda keramat dengan kepercayaan masyarakat dan juga pandangan sarjana Bali yang melihat perkaitan agama dalam semua amalan budaya dan tradisi di Bali. Dengan demikian, kedudukan sebenar cerita lisan tersebut dalam budaya kehidupan masyarakat dapat dikenal pasti di akhir makalah ini. Selain itu, makalah ini akan melihat keupayaan cerita-cerita lisan ini turut diimplementasikan dalam bidang lain yang boleh menjana ekonomi setempat misalnya menjadi sumber tarikan pelancongan. Untuk tujuan tersebut, kajian ini menggunakan metodologi kajian lapangan di beberapa kawasan yang relevan untuk pengumpulan cerita lisan dan juga menggunakan kumpulan cerita-cerita lisan yang telah dikumpulkan oleh sarjana terdahulu sebagai korpus perbincangan. Kajian ini adalah relevan kerana dapat memperkenalkan cerita lisan Bali kepada masyarakat lain di Nusantara dan juga dapat menguji sejauhmana cerita lisan tersebut benar-benar berfungsi dan mampu diimplementasikan dalam budaya hidup masyarakat pemiliknya pada zaman kini.
\end{abstract}

Kata kunci: Bali, legenda, Hindu, implementasi, kepercayaan, pelancongan. 
Abstract This paper discussed about selected oral stories found on the island of Bali, Indonesia. These oral stories were reviewed and analyzed to show what the actual oral story form is in Bali and how it is implemented in Balinese culture today. The oral narratives studied in this paper are also stories that are considered important to the people and at the same time these stories are considered sacred by the Hindus in Bali. This paper has taken into account Mohd Khalid Taib (1991) and Harun Mat Piah's (2003) views of the density between sacred legend and the beliefs of society as well as the views of Balinese scholars who examine the linkage of religion in all cultural practices and traditions in Bali. Thus, the actual position of the oral stories in the culture of the society could be identified at the end of this paper. In addition, this paper also looked at whether these oral stories are also implemented in other fields that could promote the local economy such as becoming a tourist attraction. For this purpose, this study employed a field study methodology in several areas relevant to oral storytelling and also uses a collection of oral stories gathered by previous scholars as a corpus of discussion. This study is relevant as it could introduce Balinese stories to other communities in the archipelago and also test the extent to which the oral stories are truly functional and capable of being implemented in the living culture of the owner's society today.

Keywords: Bali, legends, Hindu, implementation, belief, tourism.

\section{PENDAHULUAN}

Bali merupakan salah satu daripada 34 propinsi di Indonesia. Berkeluasan hampir $5780 \mathrm{~km}^{2}$, Bali merupakan sebuah pulau yang agak kecil berbanding Pulau Jawa mahupun Sumatera. Dengan kepadatan penduduk sekitar 4.1 juta orang yang tercatat pada $2014^{2}$, Pulau Bali terdiri daripada sembilan daerah ataupun disebut sebagai kabupaten, iaitu Kabupaten Badung, Kabupaten Gianyar, Kabupaten Jembrana, Kabupaten Bangli, Kabupaten Buleleng, Kabupaten Tabanan, Kabupaten Singaraja, Kabupaten Karangasem dan Kabupaten Klungkung. Pulau Bali juga mempunyai nama jolokan yang lain iaitu sebagai ‘Pulau Dewata' ataupun ‘ Pulau Seribu Pura'. Nama jolokan ini sebenarnya bukanlah nama yang biasa tetapi sudah memberi satu gambaran 
awal tentang situasi Pulau Bali secara fizikal dan juga amalan masyarakatnya secara umum. Masyarakatnya yang majoriti beragama Hindu di samping amalan-amalan keagamaan mereka adalah sesuatu yang akrab dan sangat berkait dengan gelaran tersebut. Bali sebenarnya mempunyai ribuan "Pura", iaitu seperti kuil tempat beribadat penganut Hindu Bali. Ada pura yang kecil yang bertaraf "Pura Keluarga" (family temple) sehinggalah kepada puluhan pura-pura besar yang dikenali sebagai Pura Kahyangan Jagat. Keberadaan binaan-binaan inilah yang menjadikan Bali sebagai 'Pulau Dewata' dan juga 'Pulau Seribu Pura'.

Di sebalik kekayaan Bali dengan budaya dan agama Hindu, Bali juga sebenarnya memiliki khazanah cerita-cerita lisan yang menarik dan meluas. 'Tradisi Satua' (tradisi bercerita) di Bali sememangnya pernah wujud sejak zaman berzaman sepertimana tradisi di negara-negara Nusantara yang lain (Suastika, 2011). Suasana berceritanya hampir sama dengan masyarakat lain, malah fungsi umumnya untuk memberi hiburan kepada masyarakat sekitar juga adalah objektif yang dikongsi oleh semua pencerita.

Permasalahan utama yang mendorong pengkaji menulis makalah ini adalah berdasarkan beberapa faktor. Pertamanya, agak sukar untuk menemui kajian khusus tentang sastera lisan Bali yang dikaitkan secara langsung dengan implementasi dalam kehidupan masyarakat Bali. Sepanjang penelitian di kampus Fakultas Sastera dan Budaya, Universitas Udayana, Denpasar, kajian khusus perkaitan sastera lisan dengan implementasi langsung dalam amalan harian masyarakatnya tidak ditemui. Namun, usahausaha pengumpulan cerita-cerita lisan Bali sudah ada. Antara kumpulan cerita yang menarik dan dijadikan sebahagian data kajian ini ialah kumpulan cerita lisan yang bertajuk "Jimat Kembang Kuning Sawit" yang diusahakan oleh I Nyoman Suarka dan I Wayan Cika³.

Selain itu, makalah ini juga diusahakan untuk menjawab persoalan apakah sebenarnya bentuk implementasi legenda Bali yang wujud pada hari ini di Pulau Dewata tersebut? Adakah ia digarap dan digunakan sebagai sumber hiburan sahaja, yakni memenuhi tuntutan tradisi 'satua' di Bali semata-mata ataupun diimplementasi dalam bentuk-bentuk lain yang lebih besar manfaat dan kesannya kepada kehidupan masyarakat 
secara keseluruhannya? Seterusnya, hal yang ingin dipastikan adakah ia masih lestari dan mampu dilihat sehingga hari ini? Dua perkara inilah yang menjadi permasalahan utama kepada kajian ini untuk dirungkai dan ditemukan jawapannya.

\section{KAJIAN LEPAS}

Sememangnya tidak dinafikan bahawa sarjana dan pengkaji sebelum ini telah banyak meneliti dan menulis tentang warisan sastera dan budaya Bali. Pelbagai topik dan fokus kajian telah ditemui semasa pembacaan yang dilakukan di Universiti Udayana dan juga buku-buku kajian yang ditemui di sekitar Bali. Antaranya ialah kajian dan pengumpulan cerita lisan oleh I Nyoman Suarka dan I Wayan Cika (2013) yang bertajuk "Jimat Kembang Kuning Sawit”. Buku kecil ini mengandungi sembilan cerita lisan Bali. Cerita ini ialah legenda keramat kerana dikaitkan dengan tokoh-tokoh dan watak-watak kepercayaan yang dianggap suci, mempunyai lelebihan luar biasa dan benar-benar berlaku suatu masa lalu oleh masyarakat Bali yang beragama Hindu.

Kajian oleh I Made Suastika (2011) pula berkisar tentang tradisi bercerita di Desa Sakardi, Kacamatan Kintamani, Kabupaten Bangli, Bali. Kajian beliau tentang tradisi bercerita ini hampir sama dengan kajian tentang cerita-cerita rakyat yang ada di Malaysia. Antara lain kajian beliau meliputi korpus dan fungsi cerita lisan yang ada di daerah tersebut. Ni Wayan Sidanadi (2014) dalam tesis sarjana di Universitas Udayana, Bali turut pernah mengkaji tentang Cerita Sri Sedana di Kabupaten Tabanan, Bali. Cerita ini berkisarkan tentang Dewa Padi yang dikatakan punca rezeki masyarakat di daerah tersebut suatu masa lalu. Kajian beliau menjurus kepada sejauhmana masyarakat sekarang menerima cerita tersebut dan mengamalkan petua-petua yang diperturunkan dalam cerita itu dan juga penerimaan masyarakat moden terhadap cerita tersebut pada hari ini.

Kajian-kajian tentang kebudayaan dan warisan tradisi lisan Bali yang lain banyak dilakukan. Antaranya kajian oleh I Wayan Geria (2000) tentang transformasi budaya Bali. Beliau menghuraikan tentang kebudayaan Bali 
yang terbahagi kepada tiga iaitu Tradisi Kecil (tradisi lisan), Tradisi Besar (keagamaan/upacara) dan Tradisi Moden. Walaupun secara asasnya terpisah, kajian beliau menunjukkan kewujudan saling berkaitan antara ketiga-tiga kategori tersebut. Penulis yang sama sekali lagi menerbitkan hasil kajiannya pada 2010 tentang inventori kebudayaan Bali. Kajiannya ini penting kerana beliau menghimpunkan keseluruhan budaya Bali, termasuklah tradisi lisan di Bali. Beliau telah mengkategorikan budaya Bali dalam tiga dimensi iaitu tangible dan abstrak.

Walaupun telah ada kajian-kajian yang menyentuh tentang tradisi lisan di Bali, kajian khusus yang mengaitkan secara langsung tradisi lisan yang berbentuk cerita dengan amalan budaya hidup masyarakat masih sukar ditemui. Kelompangan ini menyebabkan khalayak di Nusantara ini tertanya-tanya apakah sebenarnya bentuk cerita lisan yang ada Bali dan juga cerita-cerita yang diketahui malah cerita-cerita yang dikagumi oleh masyarakat Bali secara keseluruhannya? Oleh hal yang demikian, makalah ini akan meneliti cerita-cerita lisan yang sangat berkaitan dengan kehidupan umum masyarakat Bali dan pada masa yang sama cerita tersebut diimplementasikan dalam hidup mereka sehingga hari ini.

Berikut disertakan sinopsis cerita legenda keramat Bali yang dijadikan fokus perbincangan seterusnya ${ }^{4}$.

\section{Sinopsis}

\section{"Cerita Tanah Lot"}

Kisah ini berlatarkan suatu tempat dalam Kabupaten Badung di selatan Pulau Bali. Dikisahkan seorang penyebar agama Hindu yang bernama Dang Hyang Nirarta yang datang dari Jawa Timur ingin meluaskan agama tersebut di Pulau Bali. Dalam perjalanan itu, beliau mendapati ada sebuah tempat yang kelihatan cahaya suci memancar. Beliau menuju ke tempat tersebut iaitu suatu sumber mata air di tepi laut. Di situ juga terletaknya sebuah batu karang yang besar. Dang Hyang Nirarta merasakan tempat tersebut sangat baik dan suci serta sesuai dijadikan tempat bermeditasi. Beliau akhirnya mula bertapa di tempat tersebut dan mulai berdakwah kepada masyarakat disekitarnya. Walau bagaimanapun, di tempat tersebut 
ada seorang ketua bernama Bendesa Beraban Sakti. Dia ialah ketua penganut agama monoteisme. Dia sangat marah kerana penganutnya mula lari dan mengikut ajaran agama Hindu yang dibawa oleh Dang Hyang Nirarta. Bendesa Beraban Sakti mula mengganggu dan mengancam Dang Hyang Nirarta. Oleh kerana bimbang akan keselamatan penganut Hindu, maka dengan kesaktiannya beliau telah menolak batu karang besar itu ke tengah laut dan jauh dari pantai. Itulah sebabnya disebut Tanah Lot, iaitu tanah di tengah lautan. Kedudukan di tengah lautan menyebabkan Bendesa Beraban tidak dapat mengganggunya. Dang Hyang Nirarta juga mencipta ular-ular untuk menjaga persekitaran batu karang besar tersebut. Maka, mereka pun terus beribadat dan melakukan upacara agama di batu karang tersebut. Sehingga hari ini tempat beribadat tersebut masih kekal digunakan oleh penganut Hindu di Bali.

(Sumber: Rakaman penulis dan diceritakan oleh Nyoman Sudarmawan, 30 tahun)

\section{"Cerita Tirta Empul"}

Kisah ini diperoleh dari Kacamatan Tampak Siring dalam Kabupaten Gianyar, Bali. Tirta bermaksud air, manakala empul pula bermakna suci/ penawar. Cerita Tirta Empul ini bermula apabila ada seorang raja yang bernama Maya Denawa yang memerintah Bali suatu masa lalu. Malangnya sepanjang pemerintahan, Maya Denawa telah melakukan pelbagai kezaliman dan menyebabkan rakyatnya menderita. Tidak lama selepas itu, muncul seorang raja yang lain iaitu Dewa Indra yang ingin menamatkan kezaliman yang berlaku. Raja Dewa Indra sangat handal, menyebabkan Raja Maya Di Nawa mulai takut. Akhirnya dia pun lari meninggalkan istana menuju ke dalam hutan. Raja Dewa Indra telah mengejar untuk menangkapnya. Maya Denawa memiliki tapak kaki yang besar dan menyebabkan jejaknya mudah dikesan. Beliau akhirnya telah memiringkan tapak kakinya supaya tidak kelihatan lagi bekas tapak kaki. Itulah disebut desa itu sebagai Tampak Siring, yakni tapak kaki yang dimiringkan. Walaupun begitu, Dewa Indera bersama askar-askarnya terus mengejar Maya Denawa di dalam hutan belantara. Maka, apabila tiba pada suatu tempat yang ada sumber air, Maya Denawa telah mendapat akal untuk membunuh Dewa Indera dan askar- 
askarnya. Beliau tahu bahawa Dewa Indera pasti keletihan dan akan minum air di situ. Akhirnya dengan menggunakan kesaktiannya, Maya Di Nawa telah meracun sumber air di situ. Seperti diduga, askar-askar Dewa Indera yang tiba di situ dalam keadaan yang letih telah minum air tersebut dan mati serta-merta. Dewa Indera yang tahu bahawa itu adalah permainan sihir Maya Denawa, maka dia juga menggunakan kesaktiannya untuk menyucikan dan menawarkan semula racun tersebut. Sebab itulah tempat tersebut dinamakan Tirta Empul, iaitu air yang suci dan juga penawar. Sehingga hari ini, kolam tersebut masih ada malah didirikan pura iaitu tempat ibadat Hindu di situ. Sumber air tersebut terus dikunjungi oleh orang ramai untuk mandi di tempat tersebut kerana mempercayai bahawa air itu boleh menjadi penawar kepada beberapa penyakit.

(Sumber: Rakaman Penulis

Pencerita: Wayan Sujiana \& Nyoman Sudarmawan

Umur: 56 tahun dan 30 tahun)

\section{"Cerita Naga Basuki"}

Kisah ini berlatarkan sebuah desa yang bernama Desa Besakih dalam Kabupaten Karangasem, Bali. Dikisahkan ada seekor naga besar yang mendiami sebuah gua di desa tersebut. Naga yang bernama Naga Basukih/ Basuki itu sering dikunjungi oleh seorang raja yang bernama Mpu Sidimantra dari Jawa. Raja itu sering membawa perjamuan kepada naga tersebut dengan tujuan untuk memperoleh ilmu kebatinan dengan tujuan menjaga kesejahte raan dan keselamatan rakyatnya. Kunjungan itu dilakukan sejak sekian lama sehinggalah pada suatu hari, Mpu Sidimantra tidak dapat hadir ke Desa Besakih dan menghantar puteranya yang bernama Ida Manik Angkeran menemui naga tersebut. Ida Manik Angkeran ini sebenarnya seorang yang mempunyai perilaku agak buruk iaitu gemar berjudi. Dia pun menemui naga tersebut dan membawa pesanan ayahnya. Namun apabila naga tersebut berpusing untuk masuk semula ke dalam gua, Manik Angkeran terlihat di hujung ekor naga itu ada sebutir intan permata. Tanpa melengahkan masa, Manik Angkeran mencapai pisau yang dibawanya dan terus memotong ekor naga tersebut dan melarikan intan permata itu. Naga sangat marah lalu menjilat bekas tapak kaki Manik Angkeran, dengan tiba-tiba api 
menyambar tubuh Manik Angkeran lalu hangus terbakar. Mpu Sidimantra mulai risau apabila anaknya tidak pulang ke Jawa selepas menemui naga tersebut. Akhirnya, dia pergi ke desa tersebut. Pada mulanya naga tidak mahu menemui Sidimantra namun selepas dilakukan beberapa upacara pemujaan, barulah naga itu keluar dan menceritakan semua kejadian yang berlaku. Sidimantra memohon maaf kepada Naga Basuki dan merayu supaya anaknya dihidupkan semula. Sidimantra juga berjanji akan menggunakan kesaktiannya untuk menyambung semula ekor naga tersebut. Kedua-dua mereka mencapai persetujuan dan Manik Angkeran dititahkan agar terus berada di Desa Besakih sebagai pencuci di kawasan tempat ibadat di situ. Dalam perjalanan pulang ke Jawa, Sidimantra bimbang anaknya itu akan lari ke Jawa, maka dengan menggunakan kesaktiannya dia telah membelah tanah di situ dengan tongkatnya, menyebabkan terpisah tanah Jawa dengan Bali. Di situlah Selat Bali sekarang ini.

(Sumber: Koleksi I Nyoman Suarka dan I Wayan Cika)

\section{"Cerita Rambut Siwi"}

Kisah ini berlatarkan sebuah desa di Kabupaten Jembrana, Bali. Kisah ini turut dikaitkan dengan pengembaraan Dang Hyang Nirartha dari Jawa ke Pulau Bali. Dang Hyang Nirartha telah meninggalkan Majapahit dan menuju ke timur Pulau Jawa iaitu di Pasuruan. Beliau mengajarkan agama kepada penduduk di situ. Oleh sebab beliau terkenal di situ, maka Dang Hyang Nirartha telah diundang ke Brambangan untuk mengajar agama juga di sana oleh pemerintah di situ yang bernama Sri Juru. Namun, Sri Juru telah mula menunjukkan rasa cinta kepada Dang Hyang Nirartha, menyebabkan beliau mula berundur ke bahagian yang lebih timur iaitu Pulau Bali. Di Pulau Bali, beliau memasuki Kabupaten Jembrana. Namun, usahanya menyebarkan agama di situ mendapat tentangan daripada I Gusti Ngurah Rangsasa yang juga seorang guru ajaran sesat di situ. Beliau mencabar Dang Hyang Nirartha untuk beribadat di tempat Rangsasa itu bersembahyang. Akhirnya, tempat ibadat Rangsasa itu hancur dan terbelah selepas Dang Hyang Nirartha mula sembahyang. Rangsasa akhirnya mengakui kesaktian dan kehebatan itu. Dang Hyang Nirarta akhirnya sampai di sebuah desa dalam Kabupaten Jembrana. Malangnya, penduduk desa itu sedang dilanda penyakit yang 
sangat sukar diubati. Dang Hyang Nirartha sangat bersimpati dengan keadaan di situ. Beliau akhirnya mencabut sehelai rambutnya lalu dipuja (siwi) di satu tempat ibadat di desa itu. Akhirnya semua penduduk sembuh dan penyakit pun hilang. Tempat pemujaan rambut itu telah dijadikan tempat ibadat agama Hindu yang besar dan diberi nama Pura Rambut Siwi di atas bukit di tepi laut Selat Jawa. Dang Hyang Nirartha terus mengajar agama dan memperkenalkan beberapa upacara keagamaan yang perlu dipatuhi oleh penduduk setempat. Beliau juga mengajarkan cara bersawah padi di desa tersebut. Penduduk di situ dapat hidup dengan selamat dan mempunyai sumber ekonomi yang baik selepas peristiwa tersebut.

(Sumber: Koleksi I Nyoman Suarka dan I Wayan Cika dan juga wawancara bersama I Gusti Made Sedana (58 tahun), Ketua Tempat Ibadat atau 'Pengepom' Pura Rambut Siwi)

\section{DAPATAN KAJIAN}

Berdasarkan sinopsis empat cerita tersebut, didapati ia sememangnya layak dikenali sebagai sebuah legenda memandangkan ia mengandungi elemen-elemen penting sesebuah cerita tersebut. Cerita ini lengkap dengan watak dan perwatakannya seperti watak Dang Hyang Nirartha, Mpu Sidi Mantra, Ida Manik Angkeran, I Gusti Ngurah Rangsasa dan juga watak binatang seperti Naga Basuki. Watak raja yang ada dalam cerita lisan ini pula ialah Raja Maya Denawa dan juga Raja Dewa Indera. Cerita-cerita ini boleh diklasifikasikan sebagai legenda keramat kerana watak-watak yang ditampilkan memiliki ciri keluarbiasaan, dihormati dan juga dianggap suci sehingga dikaitkan dengan pembukaan tempat ibadat utama untuk masyarakat Hindu 5 .

Dari aspek latar pula, cerita ini berlatarkan hutan belantara, istana, lokasi aneh seperti di atas batu karang yang besar dan juga gua. Unsur suspens ada dalam setiap cerita ini antaranya kehilangan Manik Angkeran di Desa Besakih yang tidak kembali ke Jawa, kolam air beracun, cabaran yang dibuat oleh satu watak kepada satu watak yang lain untuk menguji kebenaran dan sebagainya. Klimaks yang menarik pula muncul dalam setiap 
cerita ini iaitu Dang Hyang Nirartha menggunakan kesaktiannya menolak batu karang besar ke tengah laut dalam "Cerita Tanah Lot". Raja Dewa Indera pula menawarkan sumber air yang telah diracun dalam "Cerita Tirta Empul”, Naga Basuki telah menjilat jejak tapak kaki Manik Angkeran yang tidak jujur hingga hangus terbakar tubuhnya dalam "Cerita Naga Basuki", manakalah dalam "Cerita Rambut Siwi” pula digambarkan kesaktian Dang Hyang Nirartha melakukan pemujaan terhadap rambutnya sendiri untuk dijadikan penawar kepada penyakit yang melanda seluruh penduduk di sebuah desa.

Unsur pengembaraan juga ditonjolkan dalam cerita-cerita ini antaranya ialah pengembaraan Dang Hyang Nirarta untuk menyebarkan agama Hindu dari Jawa ke Bali dalam "Cerita Tanah Lot" dan "Cerita Rambut Siwi" dan juga pengembaraan Dewa Indera untuk menjejak dan membunuh raja zalim yang bernama Maya Denawa. Pertembungan protagonis dan antagonis pula ditampilkan melalui adegan Dang Hyang Nirartha dengan I Gusti Ngurah Rangsasa ("Cerita Rambut Siwi"), pertembungan Naga Basuki dengan Manik Angkeran ("Cerita Naga Basuki"), pertembungan Dang Hyang Niraratha dengan Bendesa Beraban ("Cerita Tanah Lot") dan juga pertembungan kesaktian antara Dewa Indera dengan Maya Denawa dalam "Cerita Tirta Empul". Elemen-elemen ini berupaya membuktikan bahawa ia adalah cerita lisan Bali yang lengkap plot penceritaannya.

\section{Implementasi dalam Kepercayaan}

Satu persoalan menarik ialah apakah kaitan cerita-cerita lisan ini dengan masyarakat pemiliknya? Adakah ia sekadar cerita yang dianggap dongeng dan hanya menjadi sumber bercerita kepada anak-anak kecil ataupun ia mempunyai fungsi dan status yang lebih tinggi kepada masyarakat Bali?

Petunjuk pertama yang diperoleh ialah keempat-empat cerita ini berlatarkan tempat ibadat masyarakat Bali yang beragama Hindu. Ceritacerita ini memerihalkan asal usul terbentuknya pura-pura besar di Bali. Malah, ia masih kekal utuh sebagai tempat ibadat mereka sehingga hari ini. Bertitik tolak dari sini, dapat dilihat suatu petanda awal bahawa cerita ini mempunyai kaitan dengan kepercayaan keagamaan masyarakat Bali. 
Cerita lisan yang berbentuk begini bukanlah cerita lisan biasa, sebaliknya cerita yang dianggap suci dan dipercayai bahawa ia benarbenar berlaku suatu masa lalu. Kriteria cerita yang sedemikian boleh dianggap sebagai Legenda Keramat yang agak menghampiri mitos kerana ia dianggap benar dan juga terdapat eleman kepercayaan bahawa ia dianggap suci, istimewa dan luar biasa pernah diungkapkan oleh Harun Mat Piah (2003:181-182) sebagai:

Seperti mitos, legenda juga cerita yang serius, dipercayai sebagai benar, mengandungi ciri-ciri luar biasa, misteri dan mitikal. Ia juga boleh bersifat sakral, boleh membicarakan tokoh-tokoh suci, tokoh sekular, makhluk ghaib atau manusia.

Mohd Khalid Taib (1991:256) pula telah memperincikan lagi pecahan legenda ini iaitu 'legenda nama tempat, legenda orang terkenal tempatan, legenda pendosa, legenda keramat dan memorat kepercayaan terhadap hantu'. Harun Mat Piah (2003) dan Mohd Khalid Taib (1991) menunjukkan keseragaman dalam memerihalkan tentang konsep legenda dan bersetuju bahawa terdapat legenda tertentu yang mampu membicarakan hal-hal berkaitan kisah suci dan melibatkan kepercayaan. Lebih khusus lagi, Noriah Taslim (1990:164) telah memperakui bahawa 'legenda keramat' lebih dianggap serius, 'non-secular' atau suci dan berpengaruh ke atas corak hidup masyarakat pemiliknya.

Pandangan-pandangan ini sangat bertepatan dengan legenda di Bali. Ia boleh dianggap sebagai legenda keramat kerana cerita-ceritanya berkaitan dengan kepercayaan suci sesebuah masyarakat yang melingkungi dan memiliki cerita tersebut. Cerita tersebut seakan-akan memaparkan kepada masyarakat kini tentang apa yang telah benar-benar berlaku suatu masa lalu hingga membentuk sesuatu keadaan yang mampu diterima dan dipercayai hingga ke hari ini dan ada kalanya mampu dilihat secara langsung.

Berdasarkan "Cerita Tanah Lot", kedudukan batu karang besar yang agak ke tengah laut itu sememangnya menampakkan keanehan dari sudut mata kasar. Apatah lagi ia dijadikan tempat ibadat masyarakat Hindu Bali khusus untuk beberapa desa di Kabupaten Tabanan. Jika air laut pasang, masyarakat Hindu terpaksa berperahu untuk sampai ke tempat ibadat 
tersebut. Dalam konteks sains mahupun ilmu geologi, tentunya ada beberapa teori dan penjelasan tentang factor pembentukan batu sedemikian dan juga mengapa ia boleh berada dan timbul di atas laut.

Namun, dalam konteks kepercayaan masyarakat setempat, mereka mempunyai kepercayaan sendiri tentang asal kewujudan tersebut. Mereka telah berbalik dan berpegang kukuh kepada "Cerita Tanah Lot" itu sendiri. Bagi mereka, kejadian yang berlaku ke atas Dang Hyang Niraratha semasa diganggu oleh ketua ajaran sesat di situ telah memaksa Dang Hyang Nirartha menolak batu itu ke tengah laut agar masyarakat Hindu boleh beribadat dengan selamat di atasnya (petikan "Cerita Tanah Lot"). Masyarakat setempat akan menggunakan penjelasan daripada kisah tersebut untuk memerihalkan keadaan rupa tempat ibadat mereka dan ia kekal hingga sekarang.

Selain itu, kisah ular yang diarahkan oleh Dang Hyang Nirartha untuk mengelilingi tempat ibadat tersebut serta menjaganya dari ancaman luar juga turut boleh kelihatan di sana. Ular dari baka yang diletakkan oleh Dang Hyang Nirartha dipercayai masih kekal hidup di kawasan tersebut. Malah, ular yang berada dalam satu lubang itu akan keluar berenang apabila air mulai pasang, kemudian akan balik semula ke dalam lubang tersebut apabila air kembali surut ${ }^{6}$. Bahkan, dipercayai pengunjung boleh menyentuh ular tersebut dan memohon sebarang hajat untuk ditunaikan. Inilah realitinya apabila dipadankan dengan pengertian legenda keramat apabila merujuk sesuatu yang dianggap suci dan benar-benar berlaku suatu masa lalu.

Kepercayaan yang kuat terhadap cerita-cerita legenda keramat di Bali ini juga dapat dilihat dalam satu kajian lapangan di Desa Besakih dalam Kabupaten Karangasem. "Cerita Naga Basuki” yang dipercayai berasal dari desa ini telah ditampilkan dengan pembinaan patung naga yang sangat besar berhampiran pintu masuk utama Pura Besakih. Binaan tersebut dikatakan telah dibina sejak zaman silam lagi untuk mengenang kisah tersebut yang dianggap sebagai suci kepada mereka. Naga itu yang kelihatannya sangat berkuasa sehingga raja dari Jawa pun datang mengadap naga tersebut pada zaman silam telah menjadikan watak naga tersebut sangat besar dan penting. Menurut Komang Hendra (37 tahun) ${ }^{7}$, salah seorang petugas di Pura Besakih, sejak zaman beliau kecil lagi telah diceritakan bahawa Naga Basuki 
adalah penjaga kawasan tersebut dan juga Gunung Agung di belakang Pura Besakih. Disebabkan patung naga tersebut terus kekal sehingga sekarang di situ sebagai simbol kepercayaan tersebut. Perkara ini ditegaskan lagi oleh Ida Bagus Purnama (50 tahun) yang menjadi pengiring kepada kajian lapangan ini bahawa cerita tentang naga tersebut sangat dihormati, malah nama naga tersebut sangat diketahui oleh masyarakat Hindu Bali. Bahkan, nama Pura Besakih yang sangat hampir dengan nama Naga Basuki itu juga menjadikan kisah itu terus diingati sehingga hari ini.

Namun, figura naga tersebut tidak terhad di kawasan Pura Besakih sahaja. Ukiran imej naga yang sama juga turut dibina di beberapa pura besar yang lain. Hal ini dapat dibuktikan apabila ukiran tersebut turut ditemui di Pura Rambut Siwi, Kabupaten Jembrana dan juga Pura Pulaki di Kabupaten Buleleng, iaitu kedudukan paling utara dalam Pulau Bali. Ketua-ketua pura atau disebut sebagai 'Pengepom' tersebut mengakui bahawa naga-naga itu juga sebagai simbol 'penjaga' kepada kawasan itu. Walau bagaimanapun, mereka mengatakan bahawa cerita tentang Naga Basuki yang sebenar hanyalah yang ada di Desa Besakih sahaja. Perkara yang paling penting di sini ialah kisah naga itu sememangnya diterima sebagai yang benar kepada masyarakat pemiliknya. Mereka sama sekali tidak menganggap watak itu hanyalah watak rekaan sebagai hiburan cerita semata-mata.

Kekuatan kepercayaan terhadap cerita legenda keramat Bali juga dapat dilihat menerusi "Cerita Tirta Empul” di Kacamatan Tampak Siring, Kabupaten Gianyar. Kisah Raja Maya Denawa meracun sumber air di situ dan kemudiannya kejayaan Dewa Indera menawarkan semula racun tersebut sememangnya diterima oleh masyarakat setempat. Keyakinan mendalam itu turut dizahirkan dengan pembinaan sebuah tempat ibadat di situ yang dikenali sebagai Pura Tirta Empul. Tempat yang dianggap suci dan pernah berlaku peristiwa yang besar itu dikatakan sesuai untuk didirikan tempat beribadat agama mereka. Menurut salah seorang petugas di kawasan itu, iaitu I Wayan Sujiana (56 tahun), tempat itu dianggap suci kerana kejadian kejayaan Dewa Indera menghapuskan sihir racun tersebut. Malah, keyakinan itu dijelmakan lagi dengan kunjungan masyarakat tempatan dan luar untuk mandi di kolam yang dipercayai diletakkan penawar oleh Dewa Indera dengan harapan air kolam tersebut boleh menyembuh penyakit ataupun 
dapat mengurangkan kesakitan yang sedang dideritai mereka. Bahkan, ada juga pengunjung yang membawa bekas air untuk membawa pulang air tersebut untuk diberikan kepada saudara-mara mereka yang tidak dapat hadir ke situ ${ }^{8}$. Menurut seorang lagi informan, iaitu I Nyoman Sudarmawan (30 tahun), kunjungan orang ramai ke kolam di Tirta Empul itu bukanlah perkara baru. Sejak beliau kecil lagi beliau sudah mengetahui bahawa sememangnya kolam itu dipercayai airnya boleh menyembuhkan sebarang penyakit. Kisah tentang racun itu juga telah diceritakan kepada beliau oleh bapa dan juga datuknya.

Kepercayaan terhadap kisah pengembaraan Dang Hyang Nirartha ke Kabupaten Jembrana dan juga kesaktian rambutnya yang dipuja sehingga mampu menyembuhkan penyakit penduduk desa turut diimplementasikan dalam bentuk upacara keagamaan. Tempat asal kejadian aneh tersebut turut didirikan tempat ibadat yang disebut sebagai Pura Rambut Siwi. Tempat itu dipilih kerana dianggap suci dan juga telah membuktikan bahawa kuasa Tuhan pernah ditunjukkan di tempat tersebut melalui kedatangan Dang Hyang Nirartha seorang keturunan Brahma yang ingin menyebarkan agama Hindu di Bali ketika itu. Catatan dari "Purana Rambut Siwi" (2004) ${ }^{9}$ ada mengatakan bahawa;

Di sanalah beliau melihat sebuah Pahryangan sedang dijaga oleh orang, dan mengatakan bahawa desanya sedang ditimpa grubug (penyakit yang mematikan). Oleh kerana itu kemudian anugrah beliau, kata beliau "Nah inilah rambutku disunsung oleh kalian semua". Setelah itu gembiralah mereka dan bersama-sama bersujud kepada beliau. Itulah sebabnya pahryangan tersebut kemudian bernama Pura Rambut Siwi, Dang Kahyangan disebut sampai saat ini...

Catatan dalam Purana tersebut secara tidak langsung memperkukuhkan lagi cerita lisan yang mengisahkan tentang kesaktian rambut Dang Hyang Nirartha yang mampu menyembuhkan penyakit bahaya di desa tersebut. Secara tidak langsung cerita tersebut bukan sahaja terakam secara lisan dalam memori masyarakat pemiliknya tetapi juga tercatat dalam sejarah pembinaan Pura Rambut Siwi. 
Selain itu, dalam cerita lisan ada menceritakan tentang upacara pemujaan yang dilakukan oleh penduduk desa sejurus selepas Dang Hyang Nirartha berjaya menyembuhkan penyakit mereka. Realitinya, sehingga kini upacara-upacara sedemikian terus dilakukan di Pura Rambut Siwi. Antara upacara penting yang dilakukan ialah Upacara Pujawali yang dilakukan setiap enam bulan (lihat Purana Rambut Siwi, 2004). Dengan demikian, secara tidak "Cerita Rambut Siwi” tersebut akan terus kekal dan diyakini oleh masyarakat setempat memandangkan adegan-adegan yang diceritakan dalam cerita tersebut terus berkesinambungan sehingga hari ini. Malah, bangunan puranya masih dapat dilihat secara fizikal dan upacara-upacara di pura juga masih terus dilakukan. Hal yang lebih ketara ialah papan tanda yang tertera perkataan "Pura Rambut Siwi" di pintu masuk utama mampu mengekalkan memori cerita lisan itu sendiri.

\section{Dekatnya Sastera Lisan Bali dengan Kepercayaan Agama}

Berdasarkan cerita-cerita legenda yang dibincangkan, cerita legenda keramat didapati kelihatan terlalu akrab dengan kepercayaan keagamaan masyarakat Hindu Bali. Cerita tersebut seolah-olah terus kekal hidup sehingga hari ini kerana masih wujud rupa bentuk bangunan/binaan serta upacaraupacara tertentu yang masih kekal diamalkan hingga kini. Namun, apakah sebenarnya yang menjadi inti pati kepada keakraban tersebut?

Jika Harun Mat Piah (2003), Mohd Khalid Taib (1991) dan Noriah Taslim (1990) sebagai sarjana tempatan telah menghuraikan perkaitan antara cerita legenda keramat dengan kepercayaan masyarakat pemiliknya, maka pandangan daripada pengkaji tempatan Indonesia ataupun pengkaji dari Bali juga perlu diberikan perhatian yang serius. Pengkaji tempatan yang melihat saling perkaitan dan kebergantungan antara tradisi budaya dengan kepercayaan agama sebenarnya telah melihat situasi tersebut daripada 'dalam' budaya itu sendiri.

I Wayan Geria (2000) telah melihat bahawa tradisi di Bali terbahagi kepada tiga, iaitu 'Tradisi Kecil', 'Tradisi Besar' dan 'Tradisi Moden'. 'Tradisi Kecil' itu terdiri daripada budaya tempatan ataupun seumpama tradisi lisan di Malaysia. Ia terdiri daripada ilmu pertukangan, penghasilan 
kraf, tukang besi dan juga meliputi sastera lisan, persembahan dan sebagainya. 'Tradisi Besar' pula merangkumi keagamaan, konsep dewa, sistem kasta dan juga konsep-konsep agama yang tertulis dalam sastera lontar. 'Tradisi Moden' pula merupakan manifestasi zaman penjajahan, sistem pentadbiran, sistem pertahanan, sistem pemerintahan setempat seperti desa, kecamatan, kabupaten dan propinsi.

Berdasarkan pandangan pengkaji ini, beliau merumuskan bahawa 'Tradisi Kecil' itu adalah bersifat kolektif, 'Tradisi Besar' adalah keagamaan dan 'Tradisi Moden' pula adalah budaya progresif. Namun, suatu pernyataan yang paling menarik ialah apabila beliau mengatakan bahawa 'Tradisi Besar' adalah akulturasi antara budaya lokal dengan kebudayaan dan agama Hindu yang lahirkan kebudayaan Bali tradisional (I Wayan Geria, 2000: 2-3). Maka, dalam konteks ini dapatlah dikatakan bahawa cerita legenda itu sememangnya diterima sebagai gabungan antara budaya tempatan dengan kepercayaan agama di Bali. Kata-kata I Wayan Geria (2010: 131) bahawa 'Agama Hindu adalah jiwa kebudayaan Bali' telah memberikan gambaran bahawa budaya masyarakat atau tradisi mereka sangat hampir dengan kepercayaan agama Hindu, justeru tidak hairanlah apabila ceritacerita tersebut terlihat implementasinya dalam aspek kepercayaan yang kuat. Mungkin inilah yang dikatakan bahawa gabungan antara budaya atau tradisi lisan seperti itu sememangnya dianggap suatu kesatuan penting dalam membentuk budaya Bali tradisional.

Selain itu, keberadaan tradisi lisan atau cerita lisan dalam kepercayaan agama di Bali juga turut boleh dikaitkan dengan pandangan yang dilontarkan oleh seorang pengkaji Barat yang telah mengkaji situasi agama dan budaya di Bali. Luerass (2003:15) menyatakan bahawa di Pulau Bali itu sebenarnya dipenuhi 'pelbagai warna upacara keagamaan sepanjang masa'. Pandangan beliau itu didasarkan kepada kepelbagaian upacara agama yang dijalankan di Pulau Bali seperti upacara sembahyang di pura-pura, upacara perayaan seperti Galungan, Kuningan, upacara Ngeben (membakar mayat) dan sebagainya yang hampir setiap hari dilakukan.

Realiti ini semakin menunjukkan bahawa masyarakat di Bali itu memiliki kepercayaan terhadap agama mereka yang sangat kuat dan 
ditampilkan melalui upacara-upacara atau ritual yang dilakukan sejak zaman-berzaman. Justeru, jika kembali kepada dasar perbincangan makalah ini dapatlah dibuktikan bahawa cerita-cerita legenda yang mempunyai kaitan dengan kepercayaan mereka akan terus bertahan dan diterima oleh masyarakat Hindu di Bali dengan baik. Dengan demikian, fungsi legenda keramat seperti yang disuarakan oleh beberapa sarjana sebagai cerita yang dianggap benar dan memiliki unsur sakral (Harun Mat Piah, 2003) sememangnya ada kebenarannya dalam masyarakat Bali ini.

\section{Cerita Lisan dan Implementasi Pelancongan}

Selain daripada menemukan perkaitan antara cerita lisan dengan kepercayaan keagamaan masyarakat Hindu di Bali, kajian ini juga turut menemukan satu lagi perkaitan yang sangat menarik. Jika perkaitan dengan agama sesuatu yang agak serius dan berat, namun implementasi cerita lisan yang sama ke arah menyumbang kepada ekonomi tempatan pula merupakan sesuatu yang turut berperanan besar kepada masyarakat tempatan. Tanpa disedari, cerita-cerita yang berkaitan dengan pengembaraan Dang Hyang Nirartha dan cerita-cerita Pura di Bali sebenarnya turut dijadikan sebagai salah satu bahan tarikan dalam industri pelancongan di Bali. Ceritacerita lisan tersebut akan diceritakan kepada pelancong-pelancong yang berkunjung ke pura besar di Bali oleh pemandu pelancong yang ada di tempat tersebut. Secara tidak langsung, cerita-cerita lisan itu akan menjadi salah satu sumber pengetahuan kepada pengunjung untuk mengetahui asal usul tempat tersebut, kejadian aneh yang pernah berlaku, pantang larang, mengapa bentuk fizikal sesuatu tempat tersebut sedemikian rupa dan sebagainya. Penggunaan cerita-cerita lisan ini jelas kelihatan di empat lokasi yang menjadi tarikan pelancongan iaitu di Tanah Lot (Kabupaten Badong), Tirta Empul (Kabupaten Gianyar), Desa Besakih (Kabupaten Karangasem) dan Rambut Siwi (Kabupaten Jembrana).

Dalam perbincangan awal tadi telah dinyatakan bahawa cerita lisan tersebut berkaitan dengan kepercayaan masyarakat tempatan. Namu, kini cerita-cerita itu menjadi salah satu pelengkap kepada pakej pelancongan di pura-pura besar tersebut selain daripada bentuk bangunan pura yang aneh serta lokasi pembinaan pura yang indah seperti di atas tebing laut 
dan juga di kaki gunung. Memetik kata-kata daripada Ketua Pura Rambut Siwi (Pengepom), I Made Gusti Sedana, beliau menyifatkan cerita-cerita dan sejarah sesebuah pura sememangnya mempunyai dua peranan, iaitu bersifat kerohanian dan juga bernilai komersial untuk tarikan pelancongan ke kawasan tersebut. Menurut beliau, cerita-cerita yang aneh bagi sesuatu tempat itu tentunya akan menyebabkan orang ramai ingin tahu dan juga melihat lokasi yang dimaksudkan dalam cerita tersebut.

Walau bagaimanapun, sesuatu yang lebih menarik untuk dilihat dalam konteks ini ialah sekiranya cerita-cerita itu dikatakan mampu menjadi salah satu tarikan pelancongan, maka apakah kaedah dan medium yang digunakan untuk menyampaikan cerita tersebut kepada pelancong? Masyarakat tempatan mungkin sudah mengetahui cerita tersebut secara turun temurun, tetapi masyarakat dari luar lingkungan tersebut memerlukan suatu medium atau saluran tertentu untuk mereka mengetahuinya. Berdasarkan kajian lapangan yang dijalankan, didapati masyarakat Bali telah menggunakan beberapa kaedah dalam menyebarluaskan cerita lisan mereka untuk menarik pelancong. Jika dikatakan cerita itu sebagai pelengkap kepada pakej pelancongan, maka setiap pura-pura yang besar tersebut telah menyediakan petugas-petugas untuk membawa pelancong melawat dan juga bercerita tentang kisah-kisah yang berkaitan dengan pura tersebut. Walaupun ada kalanya cerita tersebut diceritakan secara ringkas, cerita tersebut tetap sampai kepada masyarakat luar dengan kaedah sedemikian. Dari segi autoriti sumber cerita, didapati ia agak sesuai dan mantap memandangkan petugaspetugas yang dilantik untuk bercerita itu terdiri daripada mereka yang agak berumur dan tentunya mereka ini mahir dengan cerita tersebut seperti yang mereka dengari daripada generasi tempatan terdahulu. Pura Tanah Lot, Pura Tirta Empul, Pura Besakih dan Pura Rambut Siwi sememangnya menyediakan petugas ini yang dipertanggungjawabkan membawa pelancong melawat sekitar pura tersebut sambil menceritakan kisah-kisah tersebut.

Penyebaran cerita lisan sebagai tarikan pelancongan ini juga dilakukan menerusi medium bercetak dan bertulis. Selain mendapat maklumat melalui petugas tersebut, pengunjung juga berpeluang membaca cerita-cerita tersebut melalui cetakan dalam bentuk risalah dan juga dalam bentuk cetakan biasa. Pura Tanah Lot yang mempunyai kisah Dang Hyang 
Nirartha yang menolak batu ke tengah laut tersebut telah dicetak secara ringkas dalam bentuk brosur atau risalah yang cantik. Kisah tersebut dicetak pada halaman pertama risalah berkenaan dan secara tidak langsung menggambarkan cerita tersebut sesuatu yang penting untuk diketengahkan kepada pengunjung Tanah Lot. Brosur ini telah diedarkan secara percuma kepada pengunjung dalam bentuk, corak dan warna yang menarik. Menurut I Nyoman Sudarmawan, salah seorang pemandu pelancong di Bali, usaha menghasilkan brosur tersebut adalah atas inisiatif penduduk desa di sekitar Tanah Lot itu untuk menghargai cerita tersebut, selain memudahkan pengunjung mengetahui cerita di sebalik bentuk dan kedudukan pura di tengah laut itu.

Cara penyebaran yang hampir sama juga turut kelihatan di Pura Rambut Siwi. Kisah Dang Hyang Nirartha yang berjaya memulihkan penyakit aneh penduduk kampung di Jembrana itu dengan memuja rambutnya itu turut dicetak dan diletakkan dalam pejabat pentadbiran utama Pura Rambut Siwi. Ia disebut sebagai 'purana', iaitu catatan sejarah dan asal usul sesebuah pura. Cetakan tersebut adalah usaha sama antara pihak pentadbiran Pura Rambut Siwi dengan Dinas Kebudayaan Propinsi Bali. Ia telah dihasilkan pada tahun 2004 demi memastikan pengunjung, penduduk tempatan dan juga petugas di pura tersebut sentiasa mengetahui sejarah dan cerita di sebalik pembinaan pura tersebut. Usaha ini juga menampakkan keberkesanannya kerana dapat membantu mereka menyimpan cerita tersebut dalam bentuk bercetak. Mereka juga khuatir jika tidak dilakukan sedemikian, cerita tersebut akan dilupakan dan hilang begitu sahaja kerana generasi tua yang mengetahuinya pasti akan tiada juga suatu masa nanti.

Lanjutan itu, ketua pentadbir (pengepom) Pura Rambut Siwi sentiasa akan merujuk catatan tersebut untuk bercerita kepada pengunjung atau pengkaji. Menurut beliau, catatan sedemikian akan memastikan mereka dapat bercerita kepada masyarakat luar secara lebih tepat dan dapat memberikan maklumat yang lebih mendalam. Dengan cara itu juga generasi pentadbir akan datang berupaya melakukan perkara yang sama. Walau bagaimanapun, cetakan tersebut adalah terhad dan disimpan rapi oleh pentadbirnya. Ia tidak diedarkan kepada pengunjung seperti mana yang dilakukan di Pura Tanah Lot. Mereka masih belum memindahkannya dalam 
bentuk yang ringkas untuk diedarkan kepada umum. Tetapi untuk tujuan penyelidikan, pihak pentadbir tersebut akan memberikan salinan penuh tanpa sebarang halangan dan masalah.

Penyebaran cerita lisan juga dilakukan dengan cara mencetaknya dan ditampal dengan cantik seperti di papan kenyataan di kawasan yang menjadi tumpuan pelancong. Contoh ini dapat dilihat dalam Cerita Tirta Empul. Kisah tersebut secara ringkas dipaparkan di hadapan pintu masuk Pura Tirta Empul. Kawasan tempat ditampal juga mudah untuk dilihat oleh pengunjung dan semasa kajian lapangan ini dijalankan, kelihatan beberapa orang pengunjung sedang membacanya. Cerita tersebut ditulis dalam dwibahasa iaitu Bahasa Indonesia dan juga Bahasa Inggeris. Mitos dan legenda-legenda tempatan ditulis dan dicetak sedemikian rupa untuk pengetahuan dan makluman kepada pengunjung. Hasil wawancara yang dilakukan di beberapa pura yang mempunyai cerita tersendiri mendapati mereka sebenarnya lebih sukakan kaedah sedemikian kerana memudahkan pengunjung. Namun, pembiayaan yang diperlukan untuk membina papan kenyataan yang cantik dan besar menyebabkan mereka perlu menunggu bantuan daripada pemerintah sebelum membinanya.

Selain daripada kaedah yang agak konvensional, penyebaran cerita lisan di Bali juga turut menggunakan teknologi semasa sebagai salah satu medium penyebarannya. Ada juga cerita-cerita daripada Pura Besakih iaitu "Cerita Naga Basuki" yang disebarkan dalam blog-blog peminat sastera lisan Bali. Seorang sarjana folklore dari Barat, Alan Dundes (1965) pernah membayangkan situasi di mana cerita lisan atau folklore itu akan sampai kepada khalayak dengan penggunaan teknologi baharu. Pada pandangan beliau, teknologi itu tidak akan mengubah makna folklore tetapi hanya mengubah cara penyampaian kepada khalayak generasi baharu sahaja (lihat Trevor, 2009:29):

Alan Dundes was among the first folklorists during the 1970s to spot the computer's leavening folklore. "So isn't stamping out folklore; rather it is becoming a vital factor in the transmission for the generation of new folklore and it is providing an exciting source of inspiration for the generation of new folklore." 
Terdapat beberapa laman web dan blog di Indonesia yang memuatkan beberapa cerita lisan di Bali. Walaupun terdapat laman web dan blog yang secara langsung mempromosikan sesuatu kawasan pelancongan tersebut dengan cerita lisan, ada juga yang sekadar memuat naik cerita tersebut untuk memenuhi kehendak sendiri dan juga ingin memulihara cerita lisan tersebut daripada terus hilang. Salah satu contoh blog yang telah memuat naik cerita Naga Basuki ialah blog yang boleh dicapai melalui pautan http://panbelog. wordpress.com/tag/naga-basuki/. Blog ini diusahakan oleh seorang pegawai kerajaan di Bali yang bernama I Wayan Adi Sudiatmika. Dalam blog ini, beliau menggambarkan terlebih dahulu tentang kewujudan Pura Besakih, iaitu pura tertua di Bali yang terletak di Desa Besakih, Karangasem. Seterusnya, beliau memasukkan kisah tentang Naga Basuki seperti yang diketahui oleh masyarakat tempatan sehingga hari ini. Kaedah penyebaran ini adalah berbentuk moden dan ia boleh melangkaui sempadan negara memandangkan boleh diakses oleh sesiapa sahaja yang ingin menjadikan Bali sebagai lokasi pelancongan mahupun penyelidikan.

Penyebaran sebegini juga dapat dilihat dalam satu lagi laman web yang berkait secara langsung dengan promosi pelancongan. Laman web Bali Star Island yang boleh dicapai melalui http://www.balistarisland. com merupakan satu laman web yang mempromosikan beberapa tempat pelancongan ataupun disebut sebagai 'objek wisata' di Bali. Namun dalam beberapa tempat yang dipaparkan itu, pentadbir web ini telah memuat naik kisah ular milik Dang Hyang Nirartha yang dikatakan menjaga persekitaran pura Tanah Lot yang berada di tengah laut itu. Walaupun dalam konteks asal ular tersebut dianggap keramat dan suci kepada penganut Hindu di situ, dalam situasi ini kisah ular tersebut telah menjadi satu daya tarikan untuk pengunjung ke tempat tersebut. Dengan demikian, dapatlah disimpulkan bahawa kaedah penyebaran melalui teknologi seperti ini juga dapat melebarkan cerita tersebut kepada khalayak umum, sebagai daya penarik dan secara tidak langsung juga dapat menyumbang kepada pemuliharaan cerita itu sendiri untuk jangka masa yang lebih panjang.

Selain kaedah menyebarkan cerita lisan sebagai tarikan pelancongan di atas, terdapat satu lagi usaha mutakhir yang turut dilakukan untuk menyokong tujuan yang sama. Pada kali ini, usaha tersebut dijalankan 
oleh dua orang sarjana sastera lisan dari Fakultas Sastera dan Budaya, Universitas Udayana Bali. Mereka telah berusaha untuk mengumpul dan menyampaikan terus cerita-cerita lisan di Bali yang ringkas kepada pemandu-pemandu pelancong di Bali. Projek itu dinamakan sebagai 'Buku

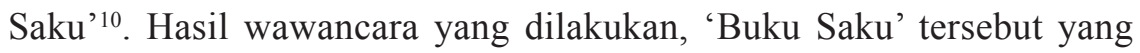
dicetak hampir 1,000 naskhah akan diedarkan kepada pemandu pelancong dengan harapan mereka akan bercerita kepada pelancong yang mereka bawa melawat di sekitar di Bali. Buku itu mengandungi cerita yang agak ringkas tentang tempat menarik yang terpilih di setiap daerah di Bali. Usaha sebegini kelihatan sangat praktikal dan berkemungkinan akan mencapai objektif untuk menyebarkan cerita lisan dalam masa yang lebih singkat dan juga tepat kepada kumpulan sasaran. Walau bagaimanapun, usaha murni tersebut sebenarnya turut bergantung kepada pemandu pelancong berkenaan untuk memastikan ia benar-benar terlaksana. Dalam hal ini, minat pemandu pelancong berkenaan terhadap cerita tersebut juga sangat diperlukan supaya mereka dapat menyampaikannya dengan baik dan bersungguh-sungguh kepada pelancong.

\section{KESIMPULAN}

Cerita lisan Bali yang boleh dikategorikan sebagai legenda keramat ini merupakan cerita lisan yang menampakkan fungsi secara langsung kepada masyarakat pemiliknya dan juga khalayak umum yang mengunjungi Pulau Bali di Indonesia. Cerita-cerita ini secara jelas telah diimplementasikan dalam kehidupan mereka sebagai salah satu asas kepercayaan yang dianuti sejak zaman zaman. Cerita-cerita ini diterima oleh masyarakat tempatan sebagai cerita yang dianggap suci dan benar-benar berlaku suatu masa lalu. Sehingga kini mereka masih mempercayai cerita tersebut dan tetap menyimpannya sebagai satu warisan leluhur mereka yang bernilai. Situasi ini menjadi sedemikian kerana konteks kehidupan masyarakat Bali itu sendiri yang telah menganggap segala amalan kebudayaan mereka termasuklah cerita-cerita legenda keramat itu sebagai sesuatu yang dekat dengan agama mereka. Malah, agama Hindu di Bali itu sendiri dikatakan menjadi jiwa kepada segala amalan budaya mereka. Cerita-cerita yang dianggap keramat dan suci itu turut berfungsi dalam konteks perkembangan 
ekonomi tempatan. Cerita itu telah terbukti menjadi sebagai salah satu tarikan pelancongan memandangkan latar cerita tersebut, iaitu lokasi pura-pura yang besar itu menjadi tempat pelancongan yang utama di Bali. Jika cerita tersebut menjadi suatu bentuk kepercayaan kepada masyarakat tempatan, maka kepada masyarakat luar cerita tersebut adalah sebagai daya penarik untuk mengunjungi Pulau Bali di Indonesia. Inilah salah satu fakta dan bukti yang jelas bahawa cerita lisan itu masih relevan dan boleh diimplementasi dalam pelbagai bentuk kehidupan manusia pada zaman ini.

\section{NOTA}

${ }^{1}$ Makalah ini adalah hasil penyelidikan semasa sabatikal di Universitas Udayana, Denpasar Bali (September 2014 - Februari 2015) dan beberapa daerah terpilih di Propinsi Bali, Indonesia.

${ }^{2}$ Rujuk portal rasmi Badan Pusat Statistik Provinsi Bali (capaian bali.bps.go.id).

${ }^{3}$ I Nyoman Suarka dan I Wayan Cika merupakan profesor sastera dan bahasa di Fakultas Sastera dan Budaya, Universitas Udayana, Kampus Denpasar, Bali.

${ }^{4}$ Di Bali sememangnya terdapat banyak legenda, tetapi makalah ini hanya memfokuskan kepada empat buah legenda ini sahaja. Pemilihan empat legenda kerana ia berfokus kepada legenda keramat dan keempat-empat legenda ini juga berkaitan dengan empat buah pura yang tertua dan terbesar di Bali. Dengan kata lain, legenda yang dipililh dalam kajian ini adalah antara yang terkenal.

${ }^{5}$ Harun Mat Piah (2003:38-44) pernah membincangkan tentang Legenda Keramat ini tetapi dalam konteks agama Islam.

${ }^{6}$ Wawancara dengan I Nyoman Sudarmawan pada 10 September 2014. Penerangan tentang cerita ini juga turut dicatat secara ringkas dalam satu risalah yang diedarkan kepada pengunjung di tempat ibadat tersebut. Ia merupakan salah satu usaha kumpulan penduduk desa tersebut untuk memberi maklumat kepada masyarakat luar yang berkunjung ke desa mereka.

${ }^{7}$ Wawancara dilakukan di Pura Besakih, Karangasem pada 6 September 2014.

${ }^{8}$ Penulis telah melakukan pemerhatian suasana di kolam tersebut ketika orang ramai mandi dan mengambil air dari situ ketika kajian lapangan pada 5 November 2014.

9 'Purana' adalah buku sejarah tentang beberapa pura di Bali. Buku ini diterbitkan oleh Dinas Kebudayaan Propinsi Bali. Di dalamnya tercatat maklumat fizikal sesebuah pura dan juga sedikit tentang sejarah awal pembinaan pura tersebut. Ada juga Purana yang mencatatkan upacara-upacara yang dijalankan di pura tersebut.

${ }^{10}$ Projek 'Buku Saku' itu adalah salah satu hasil daripada penyelidikan yang dilakukan oleh Profesor I I Nyoman Suarka dan Profesor I Wayan Cika pada tahun 2013 tentang kemampuan sastera lisan membangun sebagai sumber ekonomi di Bali. 


\section{RUJUKAN}

Dundes, A. (1965). The study of folklore. Berkeley: University of California Press. Harun Mat Piah. (2003). Sastera rakyat Malaysia, Indonesia, Negara Brunei Darusalam: Suatu perbandingan. Kuala Lumpur: Dewan Bahasa dan Pustaka.

I Gusti Ngurah Made Tara Wiguna (peny.). (2004). Purana luhur rambut siwi. Denspasar: Dinas kebudayaan provinsi Bali.

I Made Suastika. (2011). Tradisi sastera lisan (Satua) di Bali. Bali: Pustaka Lerasan dan Program Studi Magister dan Doktor Kajian Budaya Udayana.

I Nyoman Suarka \& I Wayan Cika. (2013). Jimat kembang kuning sawit (Cerita lisan Bali). Bali: Universitas Udayana.

I Wayan Geria. (2000). Transformasi kebudayaan Bali memasuki abad XXI. Bali: Dinas Kebudayaan Propinsi Bali.

I Wayan Geria. (2010). Kebudayaan unggul: Inventori unsur keunggulan sebagai basis Kota Denpasar Kreatif. Bali: Bappeda, Kota Denpasar.

Leuras, L. (Ed.). (2003). Bali eye of Indonesia. Bali: Yayasan Kemanusiaan Indonesia.

Mohd. Khalid Taib. (1991). Legenda-legenda nama tempat dan orang terkenal di Semenanjung Malaysia. Dalam Mohd Taib Osman (Pngr.), Pengkajian sastera rakyat bercorak cerita. Kuala Lumpur: Dewan Bahasa dan Pustaka.

Ni Wayan Sidanadi. (2014). "Marginalisasi Kearifan Lokal di Era Golbalisasi: Studi Satua Sri Sedana di Desa Denbatas Tabanan". Tesis Magister Fakultas Sastera dan Budaya, Universitas Udayana, Bali, Indonesia.

Noriah Taslim. (1990). Sedikit tentang makna dalam Legenda Keramat Melayu: Dilihat melalui satu analisa struktural ke atas Legenda Keramat Lebai Kader dari Kedah. Dalam Othman Daya (Ed.), Tradisi lisan bercorak cerita. Kuala Lumpur: Bahagian Kebudayaan Kementerian Kebudayaan dan Pelancongan Malaysia.

Trevor, J. (2009). Folklore and the internet. Utah: Utah State University Press.

\section{Informan}

I Gusti Made Sedana, 58 tahun, ketua pengepom (Pentadbir) Pura Rambut Siwi, Jembrana, Bali.

Profesor Dr I Nyoman Suarka, 56 tahun, Jabatan Sastera Jawa Kuna, Fakultas Sastera dan Budaya, Universitas Udayana, Bali.

Ida Bagus Purnama, 50 tahun, pemandu, Denpasar, Bali.

I Nyoman Sudarmawan, 30 tahun, pengusaha pelancongan, Denpasar, Bali.

I Wayan Sujiana, 56 tahun, pekerja Pura Tirta Empul, Gianyar, Bali.

Komang Hendra, 32 tahun, pekerja Pura Besakih, Desa Besakih, Karangasem, Bali. 